\title{
Impact of the COVID-19 Pandemic and Psychosocial Coping Strategies in Health Sciences Students at the University of Seville: A Pilot Study
}

\author{
Rocío de-Diego-Cordero ${ }^{1} \mathbb{D}$, Cristina Martínez-del-Carmen ${ }^{2} \mathbb{D}$, Patricia Bonilla Sierra ${ }^{3} \mathbb{D}$ \\ and Ana-Magdalena Vargas-Martínez ${ }^{1, * \mathbb{D}}$ \\ 1 Research Group PAIDI-CTS 969 Innovation in Health Care and Social Determinants of Health, \\ School of Nursing, Physiotherapy and Podiatry, University of Seville, 41009 Seville, Spain; rdediego2@us.es \\ 2 School of Nursing, Physiotherapy and Podiatry, University of Seville, 41009 Seville, Spain; \\ marmardel11@alum.us.es \\ 3 Health Sciences School, Private Technical University of Loja, Loja 11-01-608, Ecuador; pbonilla65@utpl.edu.ec \\ * Correspondence: avargas5@us.es
}

check for

updates

Citation: de-Diego-Cordero, R.; Martínez-del-Carmen, C.; Bonilla Sierra, P.; Vargas-Martínez, A.-M. Impact of the COVID-19 Pandemic and Psychosocial Coping Strategies in Health Sciences Students at the University of Seville: A Pilot Study. Healthcare 2021, 9, 1661. https:// doi.org/10.3390/healthcare9121661

Academic Editor: Federica Galli

Received: 25 October 2021

Accepted: 27 November 2021

Published: 30 November 2021

Publisher's Note: MDPI stays neutral with regard to jurisdictional claims in published maps and institutional affiliations.

Copyright: (c) 2021 by the authors. Licensee MDPI, Basel, Switzerland. This article is an open access article distributed under the terms and conditions of the Creative Commons Attribution (CC BY) license (https:// creativecommons.org/licenses/by/ $4.0 /)$

\begin{abstract}
The new infection by coronavirus has supposed a challenge to all health systems worldwide, affecting our psychosocial health. Education as we knew it has changed, which is why university students, attending Health Sciences courses in this case, have been affected by the pandemic. This study aimed to analyze the impact of the preventative measures and restrictions associated with COVID-19 on multiple mental health and psychological well-being indicators in Health Sciences students at the University of Seville. A descriptive and cross-sectional pilot study in the University of Seville by means of an online questionnaire elaborated was conducted. Of the final sample $(n=68)$, more than $60 \%$ of the students acknowledged having received specific training by their university and/or health institution where they perform practices on COVID-19 measures; however, they negatively emphasized not having received psychosocial aid or support in most of the cases (94.12\%). As the health situation imposed by COVID-19 is considered long-lasting, the proposal is to plan short- and long-term strategies for promotion and intervention in the mental health of students and future health care workers.
\end{abstract}

Keywords: coronavirus; students; mental health; depression; young people; psychological support

\section{Introduction}

Declaration of the pandemic by the World Health Organization (WHO) on 11 March 2020 [1], caused by the new coronavirus, put the entire world out of control. Both science and the health systems burst, the world economy collapsed, and the enormous vulnerability and fragility of mankind was revealed, in particular of those who act in the front line against this virus, including health care professionals and students attending courses in these sciences.

In Spain, the state of alarm was declared on 14 March 2020, through Royal Decree No. $463 / 2020$ [2], which included severe confinement, quarantine, and social isolation measures, with the implementation of actions to limit the virus' spread given the high morbidity and mortality it was causing at the time. Among these restrictive measures, limitation of people's circulation freedom was established, including a prolonged confinement situation that severely altered the lifestyle of a large part of the Spanish population. In case of the education sector, the closure of universities and institutions of higher education to contain the spread of the virus prevented the maintenance of university activities in their face-toface modality and they were specifically online [3]; however, in case of Health Sciences students of University of Seville, they had the possibility to continue their traineeship in the health institutions when the confinement ended. 
Some articles have been published about the impact of epidemic crises on health professionals' mental health [4] and about possible interventions to prevent potential complications [5]. However, little is known about the impact and psychosocial coping strategies of Health Sciences students, who are exposed not only to the pandemic situation but also to work-related stress, high mental burden, professional strain, moral distress, and compassion fatigue or secondary traumatic stress [6].

Levels, work-related stress, risk of contagion, and lack of suitable means, both material and human, to fight against the virus added to the quarantine situation, which limited university attendance and participation in social activities, might cause important harm to mental health, such as anxiety and depression, [7]. Recent studies have detected the onset and experience of depression and anxiety symptoms [8], as well as of Burnout [9] syndrome, in addition to personal and social impacts [10], which could affect their response capacity during the pandemic [11].

\section{Materials and Methods}

\subsection{Design}

A descriptive, correlational, and cross-sectional pilot study was conducted between 15 March 2021 and 15 May 2021, at the University of Seville (US). The state of emergency in Spain was declared on 14 March 2020 and finished 9 May 2021 [12]. During the study period, time restrictions, limited capacity in public spaces, etc. were employed but not lockdown. The end of the academic year 2019/2020 was carried out in the universities in an online mode, and during the academic year 2020/2021, the University of Seville opted for the blended mode with limited capacity in classes, so that students attended some classes online and others in person. It was carried out by means of an online questionnaire that was available to the students for 60 days from initiation of the data collection period. The approximate time to answer the entire survey was $20 \mathrm{~min}$. It included sociodemographic topics and standardized tests to assess multiple indicators related to mental health, psychological well-being, and coping styles. Participation was strictly anonymous and confidential.

Online filling-in of this questionnaire allowed the students to answer it from their electronic devices. In addition, the questionnaires' web administration minimized the risk of data loss and allowed for automatic and immediate calculation of scores, with consequent time optimization. Further, it is accepted by the general population and ensures anonymity.

All of the above was performed with prior informed consent according to Organic Law No. 3/2018 for the Protection of Personal Data and Guarantee of the Digital Rights, dated 5 December [13], with prior invitation sent via the University of Seville's institutional email service. No differentiation was made between COVID-19-positive or -negative students and there were no exclusions based on sociodemographic variables, such as gender or ethnicity.

Anonymity was ensured in two ways: by randomizing or omitting the IP information of the device in which the survey was answered and by not asking questions that allowed identification of the participant.

\subsection{Sample Size, Population, and Study Variables}

The sample was collected among undergraduate students attending Health Sciences specialties, such as Nursing, Physiotherapy, and Podiatry, at the University of Seville, and were performing practices in the 2020-2021 academic year, given during the 2019-2020 academic year, when the state of emergency was declared and confinement measures were applied (from March to June 2020), during which the students did not carry out their clinical practices. Collaboration was asked from some professors who taught in such courses to conduct the online survey; they allowed answering of the questionnaire in some of their classes as long as the participants met the criteria.

Since it was a pilot study, the sample size was calculated according to Viechtbauer et al. [14] through the formula proposed by this author to calculate the sample size required to detect 
a problem in a pilot study. In order to attain a sample that was statistically representative of our target population, according to the latest publication of the US statistical annual report, from a total of 1586 students (930 from Nursing, 384 from Physiotherapy, and 373 from Podiatry), considering a 95\% confidence level and 5\% of statistical power of the anxiety and/or depression symptoms probability, the total sample required was 59 students. This probability taken into account is lower than that found in other studies to reach a larger sample size and greater precision, given the heterogeneity of our population in relation their practices and their experience during the COVID-19 pandemic.

All students who belonged to the same class group were invited to fill in the questionnaire. A total of 164 questionnaires were initially collected, from which only 68 were valid due to incompleteness.

Of the final sample, with a mean age of $22.76 \pm 4.93$ years old, more than $80 \%$ were women $(n=57)$. The mean number of household members was around 3 individuals, with no statistically significant differences between men and women. Only $14.71 \%$ of the sample lived with an older adult requiring care. It is noted that spirituality was found in $81.8 \%$ of the men and $64.9 \%$ of the women, although this difference was not statistically significant. The predominant religious belief was the Catholic religion, accounting for $66.18 \%$ of the total sample. Regarding perception of health status, $47.06 \%$ mentioned good physical health status; however, in the case of mental health, there was a higher percentage among those who indicated that it was fair (38.24\%) against 33.83\% who reported good mental health status. In relation to the practices and studies of the sample analyzed, $92.65 \%$ consisted of Nursing students, who mostly performed their practices in institutions belonging to the public health system with a part-time regime, and who stated having "some" freedom and supervision while performing their practices.

\subsection{Measuring Instruments}

The questionnaire used was divided into 3 major blocks: the first, consisting of sociodemographic questions and related to health sciences students' practices characteristics; the second, elaborated with questions related to COVID-19 at the personal and family levels and concerning the perceived help from the university; and the third, in which 9 validated scales were used to assess multiple mental health and psychological well-being indicators and coping styles (Table 1).

Table 1. Scales used.

\begin{tabular}{|c|c|c|}
\hline $\begin{array}{l}\text { Scales Used and Psychometric } \\
\text { Characteristics }\end{array}$ & Definition & Score-Measurement \\
\hline $\begin{array}{l}\text { Perceived Stress Scale } \\
\text { (PSS-14) [15]. } \\
\alpha=0.81\end{array}$ & $\begin{array}{l}\text { It assesses the level of perceived stress in the } \\
\text { last month }\end{array}$ & $\begin{array}{l}\text { It consists of } 14 \text { items with an answer format in } \\
\text { a five-point scale }(0=\text { never, } 1=\text { almost never, } \\
2=\text { occasionally, } 3=\text { often, and } 4=\text { very often). } \\
\text { The total score of the PSS scale is obtained by } \\
\text { reversing the scores of items } 4,5,6,7,9,10 \text { and } \\
13 \text { (in the following order: } 0=4,1=3,2=2 \text {, } \\
3=1 \text { and } 4=0) \text { to then add up the } 14 \text { items. } \\
\text { The direct score obtained indicates that higher } \\
\text { values correspond to higher levels of } \\
\text { perceived stress. }\end{array}$ \\
\hline $\begin{array}{l}\text { UCLA Loneliness Scale (Revised Version, } \\
\text { Short Version) UCLA-R [16] } \\
\text { Kaiser-Meyer-Okin }(\text { KMO) }=0.839\end{array}$ & $\begin{array}{l}\text { It assesses the subjective feelings of loneliness, } \\
\text { as well as those of social isolation. }\end{array}$ & $\begin{array}{l}\text { It has } 20 \text { items, although only } 3 \text { have been } \\
\text { selected. The participants had to choose one of } \\
4 \text { possible answers: never, rarely, sometimes } \\
\text { or always. }\end{array}$ \\
\hline $\begin{array}{l}\text { Avoidance and Action Questionnaire II } \\
\text { (AAQ-II) [17]. } \\
\text { Kaiser-Meyer-Olkin }(\mathrm{KMO})=0.087\end{array}$ & $\begin{array}{l}\text { It assesses experiential avoidance or, on the } \\
\text { contrary, psychological resilience, depending } \\
\text { on the orientation of its ten reagents. }\end{array}$ & $\begin{array}{l}\text { It consists of } 7 \text { reagents, each one with seven } \\
\text { answer options varying from "never" to } \\
\text { "always", according to the beliefs. Higher total } \\
\text { scores mean less resilience, whereas lower } \\
\text { overall scores indicate more resilience } \\
\text { regarding the experiences went through by } \\
\text { each individual. }\end{array}$ \\
\hline
\end{tabular}


Table 1. Cont.

\begin{tabular}{|c|c|c|}
\hline $\begin{array}{l}\text { Scales Used and Psychometric } \\
\text { Characteristics }\end{array}$ & Definition & Score-Measurement \\
\hline $\begin{array}{l}\text { Brief Resilience Scale (BRS) [18] } \\
\text { Kaiser-Meyer-Olkin }(\mathrm{KMO})=0.793\end{array}$ & $\begin{array}{l}\text { It assesses people's ability to recover from } \\
\text { stressful circumstances. This resilience can be } \\
\text { particularly important for people who are } \\
\text { dealing with stressful life events, such as } \\
\text { health-related problems. }\end{array}$ & $\begin{array}{l}\text { It consists of } 6 \text { items with a } 5 \text {-point answer } \\
\text { scale varying from } 1 \text { (totally disagree) to } \\
5 \text { (totally agree). Higher scores indicate } \\
\text { more resilience. }\end{array}$ \\
\hline $\begin{array}{l}\text { The Alcohol Use Disorders Identification } \\
\text { Test: Self-Report Version (AUDIT-C) [19-21] } \\
\alpha=0.75\end{array}$ & $\begin{array}{l}\text { It measures excessive alcohol consumption. It } \\
\text { can assist in the identification of excessive } \\
\text { alcohol consumption as the cause of the } \\
\text { current disease. It also provides a framework } \\
\text { for the intervention to assist drinkers with } \\
\text { harmful or risk consumption in reducing or } \\
\text { ceasing alcohol consumption, so that they can } \\
\text { avoid the detrimental consequences } \\
\text { of consumption. }\end{array}$ & $\begin{array}{l}\text { It has } 10 \text { items, each one scored from } 0 \text { to } \\
4 \text { points. We have only used three of them. } \\
\text { It is scored from } 0 \text { to } 12 \text {, as follows: low risk if } \\
\text { below } 2 \text {, moderate risk between } 3 \text { and } 5 \text {, high } \\
\text { risk between } 6 \text { and } 7 \text {, and severe risk between } \\
8 \text { and } 12 \text { (for women), only differing in low } \\
\text { risk (0-3) and medium risk (4-5) for men. }\end{array}$ \\
\hline $\begin{array}{l}\text { Patient Health Questionnaire (PHQ-4) [22] } \\
\alpha=0.903\end{array}$ & $\begin{array}{l}\text { It assesses the patients' level of psychological } \\
\text { distress and characterizes their symptoms as of } \\
\text { anxiety and/or depression, predominantly. }\end{array}$ & $\begin{array}{l}\text { It consists of } 4 \text { items, two of them for screening } \\
\text { depression and the other two for screening } \\
\text { anxiety. These items have been extracted from } \\
\text { two different scales and validated at the } \\
\text { international level. Significantly high scores } \\
\text { are generally considered as those equal to or } \\
\text { greater than half of the maximum score, that is, } \\
\text { PHQ-4 } \geq 6 \text {. }\end{array}$ \\
\hline $\begin{array}{l}\text { Life Satisfaction Questionnaire (LSQ) [22] } \\
\text { Kaiser-Meyer-Olkin }(\mathrm{KMO})=0.847\end{array}$ & $\begin{array}{l}\text { It assesses perception of quality of life in } \\
\text { women with breast cancer. This instrument } \\
\text { can also be used in complementary treatments. }\end{array}$ & $\begin{array}{l}\text { It consists of } 34 \text { items (in this study, only one } \\
\text { of them was selected, whose question is as } \\
\text { follows: Which is your overall level of satisfaction } \\
\text { with life?). It is scored with a value between } 1 \\
\text { and } 7 \text {, where the higher the score, the greater } \\
\text { the satisfaction level. }\end{array}$ \\
\hline & & $\begin{array}{l}\text { It has } 26 \text { items. In 2011, a shorter version of the } \\
\text { SCS scale was developed, with only } 12 \text { items. } \\
\text { Coding key: }\end{array}$ \\
\hline $\begin{array}{l}\text { SCS Compassion Scale in Spanish (12-item } \\
\text { version) }[23] \\
\text { Kaiser-Meyer-Olkin }(\mathrm{KMO})=0.79\end{array}$ & It assesses an individual's level of compassion. & $\begin{array}{ll}- & \text { Self-kindness, items: } 5,12,19,23,26 \\
\text { - } & \text { Common humanity, items: } 3,7,10,15 \\
\text { - } & \text { Mindfulness, items: } 9,14,17,22 \\
\text { - } & \text { Self-judgment, items: } 1,8,11,16,21 \\
\text { - } & \text { Isolation, items: } 4,13,18,25 \\
& \text { Overidentification, items: } 2,6,20,24\end{array}$ \\
\hline $\begin{array}{l}\text { Functional Assessment of Chronic Illness } \\
\text { Therapy-Spiritual Well-Being (FACIT-SP) } \\
\text { [24] } \\
\alpha=0.835\end{array}$ & $\begin{array}{l}\text { It assesses aspects related to spiritual } \\
\text { well-being related to the meaning and purpose } \\
\text { of life, peace and the sensation of strength and } \\
\text { comfort derived from faith and from } \\
\text { spiritual beliefs. }\end{array}$ & $\begin{array}{l}\text { It has } 12 \text { items. It is evaluated with a } 5 \text {-point } \\
\text { scale, varying from } 0 \text { (not at all) to } 4 \text { (very } \\
\text { much). Higher scores indicate higher levels of } \\
\text { spiritual well-being. }\end{array}$ \\
\hline
\end{tabular}

Regarding health sciences students' practice characteristics, freedom perceived while performing their practice is understood as the freedom to choose the tasks or procedures to be carried out, schedules, number of clinical cases to attend, etc., and supervision perceived while performing their practice refers to the review by an expert healthcare professional of the tasks or procedures that students perform, the evaluation of their progress, and the support or guidance received.

\subsection{Data Analysis}

A descriptive analysis about the sociodemographic characteristics related to the practices in health institutions and with the experience during the COVID-19 pandemic was performed with the use of mean values and standard deviations in the case of the numerical variables, and resorting to absolute and percentage (\%) frequencies for the categorical variables. No analyses by group (sex or another) were performed due to the sample size and difference in proportion between groups. A correlation analysis was performed (Pearson's when distribution of the variables followed normality, and Spearman's when that was not the case). The associations between different sociodemographic variables and those 
related to experience during the COVID-19 pandemic with the variables studied by means of the different scales applied, namely: perceived stress level, risk alcohol consumption, level of psychological distress, psychological resilience in the face of the experiences, selfcompassion, spiritual well-being, resilience, and feeling of loneliness, were studied by means of correlation analysis (Pearson's when the distribution of the variables followed normality, and Spearman's when that was not the case) since, to such an end, the overall score of each scale was used. These coefficients were classified as: "high degree": if the coefficient value lies between \pm 0.50 and \pm 1 , then it is said to be a strong correlation; "moderate degree": if the value lies between \pm 0.30 and \pm 0.49 , then it is said to be a medium correlation; and "low degree": when the value lies below +0.29 , then it is said to be a small correlation.

Some variables, such as age, were centered by using medians, as no 0 value was included in these variables for the sample under study. The data were analyzed in the $\mathrm{R}$ software (version R-3.6.3, GNU General Public License from the Free Software Foundation: https: / / www.r-project.org/about.html, accessed on 12 October 2021). A $p$-value $<0.05$ was accepted as statistically significant.

\section{Results}

Regarding the data related to the COVID-19 pandemic and to the Health Sciences students' experience, it is noted that more than $60 \%$ of them acknowledged having received specific training on this topic by their university and/or health institution where they perform their practices. It is also negatively noted that they did not receive any psychoemotional aid or support in most of the cases $(94.12 \%)$. In relation to having family members and / or close friends who are at risk of a positive COVID-19 diagnosis or who have died due to diseases related to a positive COVID-19 diagnosis, 21 (30.88\%) and $15(22.06 \%)$ students experienced these circumstances, respectively. Despite the pandemic situation, the clinical care provided by most of the students during their internships in health centers was mostly face-to-face $(64.71 \%)$, and $29.41 \%$ of the students that make up the sample reported having taken isolation measures, leaving their family home where they live with their parents during the period of their clinical practice.

Regarding the different scales that were applied to the sample, their mean scores can be seen in Table 2 .

Table 2. Scores in the scales.

\begin{tabular}{cc}
\hline Variables & Total Sample $\boldsymbol{n = 6 8}$ \\
\hline Perceived Stress Scale (PSS-14) & $28.57(8.84)$ \\
\hline UCLA Loneliness Scale (Revised Version, Short Version) & \\
UCLA-R & \\
How often do you feel that you lack companionship? & $7(10.45)$ \\
Never & $16(23.88)$ \\
Rarely & $35(52.24)$ \\
Sometimes & $9(13.43)$ \\
Always & \\
How often do you feel left out? & $19(28.36)$ \\
Never & $26(38.81)$ \\
Rarely & $18(26.87)$ \\
Sometimes & $4(5.97)$ \\
Always & \\
How often do you feel left isolated from others? & $25(37.31)$ \\
Never & $26(38.81)$ \\
Rarely & $13(19.40)$ \\
Sometimes & $3(4.48)$ \\
\hline
\end{tabular}


Table 2. Cont.

\begin{tabular}{cc}
\hline Variables & Total Sample $n=\mathbf{6 8}$ \\
\hline Avoidance and Action Questionnaire II (AAQ-II) & $22.52(10.37)$ \\
24 points & $27(40.3)$ \\
\hline Brief Resilience Scale (BRS) & $17.84(2.47)$ \\
AUDIT-C & $32(47.76)$ \\
Low risk (0-2 points for women; 0-3 for men) & $24(35.82)$ \\
Moderate risk (3-5 points for women; 4-5 points for men) & $10(14.93)$ \\
High risk (6-7 points) & $1(1.49)$ \\
Severe risk (8-12 points) & $4.99(3.43)$ \\
\hline 6 points (predominance of anxiety and/or depression) & $27(40.3)$ \\
\hline Life Satisfaction Questionnaire (LSQ) & \\
Which is your overall level of satisfaction with life? & $6.46(2.34)$ \\
\hline SCS Compassion Scale in Spanish (12-item version) & $38.15(9.16)$ \\
Self-kindness subscale & $5.94(2.13)$ \\
Self-judgment subscale & $6.57(2.14)$ \\
Common humanity subscale & $5.81(1.72)$ \\
Isolation subscale & $7.15(2.52)$ \\
Mindfulness subscale & $6.39(2.03)$ \\
Overidentification subscale & $6.30(2.36)$ \\
\hline Functional Assessment of Chronic Illness & $27.05(6.58)$ \\
Therapy-Spiritual Well-Being (FACIT-SP) & \\
\hline
\end{tabular}

Note: Mean values and standard deviations are presented in between round brackets for quantitative or numerical variables, and absolute and percentage frequencies are indicated in between round brackets for categorical variables.

Regarding the stress perceived through the PSS-14 tool, the mean score reached a mid-position in relation to the maximum score, since a mean of $28.57 \pm 8.84$ out of a total of 56 points was obtained.

In relation to the items assessed in the UCLA-R about feelings of loneliness, more than $50 \%$ mentioned that they sometimes felt a lack of companionship. Regarding psychological resilience and the risk of suffering anxiety or depression symptoms, through the AAQ-II scale, it is concluded that $40.3 \%$ of the students obtained a score equal to or greater than 24 , which indicates a predominance of these symptoms and less psychological resilience in the face of life experiences.

This coincides with the PHQ-4 questionnaire, where the same percentage of patients in which there was a predominance of anxiety and/or depression was obtained, with a score equal to or greater than six points in this case. Regarding the resilience level, it is around the scale's mean score since the maximum possible value is 30 .

In relation to risk alcohol consumption, assessed through the AUDIT-C questionnaire, $47.76 \%$ were at low risk and $35.82 \%$ were at moderate risk.

Regarding satisfaction with life, assessed only through one item from the LSQ scale, it could be asserted that it was high since, out of 7 points, the mean was $6.46 \pm 2.34$. Finally, regarding self-compassion, it is noted that there were statistically significant differences between men and women, finding more self-compassion among the former.

Regarding the scales, high, positive, and statistically significant correlations weere observed between PSS-14 and AAQ-II, between PSS-14 and PHQ-4, and between PHQ-4 and AAQ-II, as well as between FACIT-SP and SCS. High, although negative, correlations (that is, when the overall score of one scale increases, the other's decreases) were also observed between PSS-14 and SCS, between PSS-14 and FACIT-SP, between AAQ-II and SCS, and between AAQ-II and FCIT, as well as between PHQ-4 and SCS (Table 3). 
Table 3. Correlations between the scales.

\begin{tabular}{|c|c|c|c|c|c|c|c|}
\hline Scales & PSS-14 & AAQ-II & BRS & PHQ-4 & LSQ & SCS & FACIT-SP \\
\hline PSS-14 & $1(0)$ & & & & & & \\
\hline AAQ-II & $0.698^{* * *}$ & $1(0)$ & & & & & \\
\hline BRS & $0.101(0)$ & $0.103(0)$ & $1(0)$ & & & & \\
\hline PHQ-4 & $0.796^{* * *}$ & $0.772 * * *$ & $0.131(0)$ & $1(0)$ & & & \\
\hline LSQ & $-0.251 * *$ & $-0.286 * *$ & $-0.036(0)$ & -0.213 * & $1(0)$ & & \\
\hline SCS & $-0.707^{* * *}$ & $-0.697 * * *$ & $-0.078(0)$ & $-0.656^{* * *}$ & $0.157(0)$ & $1(0)$ & \\
\hline FACIT-SP & $-0.597 * * *$ & $-0.556 * * *$ & $-0.044(0)$ & $-0.485^{* * *}$ & $0.304^{* *}$ & $0.595 * * *$ & $1(0)$ \\
\hline
\end{tabular}

***, ** and ${ }^{*}$ represent $1 \%, 5 \%$ and $10 \%$ statistical significance. PSS-14: Perceived Stress Scale; AAQ-II: Avoidance and Action Questionnaire II; BRS: Brief Resilience Scale; PHQ-4: Patient Health Questionnaire; LSQ: Life Satisfaction Questionnaire; SCS: Compassion Scale in Spanish; FACIT-SP: Functional Assessment of Chronic Illness Thera-py-Spiritual Well-Being.

Additional correlation analyses were performed to study the association between the different variables assessed by means of the scales and the data collected regarding sociodemographic aspects, experience during the pandemic, and perception of the Health Sciences students about their health status (Tables 4 and 5).

Regarding the perception of mental health status in the last 30 days, high, negative, and statistically significant correlations were observed between this variable and perceived stress (PSS-14), the risk to suffer anxiety or depression symptoms (AAQ-II and PHQ-4), and so less psychological resilience, indicating that a lower score in these scales is associated with a better perception of mental health status and vice versa, given that a lower score indicates lower perceived stress and a lower risk of suffering anxiety or depression symptoms. High, although positive, correlations were observed between the perception of mental health status and self-compassion and spiritual well-being, indicating that a better perception of mental health is associated with higher levels of compassion and spiritual well-being.

Related to age, only the predominance of anxiety and/or depression symptoms (PHQ-4) and life satisfaction level (LSQ) were found to be associated with this. Given that this correlation was negative, older people scored lower in those scales, indicating a lower predominance of anxiety and/or depression symptoms and lower life satisfaction level.

Regarding spirituality, those who considered themselves spiritual people obtained a lower score in AAQ-II, meaning that they had better psychological resilience in the face of the experiences.

Regarding having family members and/or close friends who are at risk of COVID-19, low-moderate, positive, and statistically significant correlations were observed between this variable and spiritual well-being and alcohol use disorders.

Regarding health sciences students' practices characteristics, low-moderate, negative, and statistically significant correlations were observed between freedom perceived while performing their practices (understood as the freedom to choose the tasks or procedures to be carried out, schedules, number of clinical cases to attend, etc.) and perceived stress (PSS-14) and the risk of anxiety and/or depression symptoms (AAQ-II and PHQ-4). However, a positive association was observed between freedom perceived while performing their practices and compassion level. These associations were studied given that the stress level of the health sciences student can be increased in a pandemic situation as a consequence of the management in health centers in terms of staffing and lack of knowledge in the management of the disease, resulting in stress of the health professionals who work in the centers [25] who must monitor the progress of the students. 
Table 4. Associations between different psychological outcomes and experience during the COVID-19 pandemic among health sciences students.

\begin{tabular}{|c|c|c|c|c|c|c|c|c|}
\hline & Age & Gender & Spirituality & $\begin{array}{c}\text { Perception of } \\
\text { Physical Health } \\
\text { Status (Last } 30 \text { Days) }\end{array}$ & $\begin{array}{c}\text { Perception of Mental } \\
\text { Health Status (Last } \\
\text { 30 Days) }\end{array}$ & $\begin{array}{c}\text { Family Members } \\
\text { and/or Close Friends } \\
\text { Who Are at Risk of } \\
\text { COVID-19 }\end{array}$ & $\begin{array}{c}\text { Family Members } \\
\text { and/or Close Friends } \\
\text { Who Have Died due } \\
\text { to COVID-19 }\end{array}$ & $\begin{array}{c}\text { Changes } \\
\text { IMPLEMENTED } \\
\text { since the Beginning } \\
\text { of the Pandemic }\end{array}$ \\
\hline PSS-14 & $-0.170(-0.398 ; 0.077)$ & $0.113(-0.134 ; 0.348)$ & $-0.139(-0.370 ; 0.109)$ & $-0.204(-0.426 ; 0.042)$ & $-0.669(-0.785 ;-0.508) * * *$ & $-0.180(-0.406 ; 0.066)$ & $-0.011(-0.254 ; 0.234)$ & $0.074(-0.173 ; 0.313)$ \\
\hline PHQ-4 & $-0.250(-0.462 ;-0.010) * *$ & $-0.037(-0.275 ; 0.205)$ & $-0.145(-0.372 ; 0.099)$ & $-0.122(-0.352 ; 0.122)$ & $-0.744(-0.835 ;-0.613)^{* * *}$ & $-0.189(-0.411 ; 0.054)$ & $-0.040(-0.277 ; 0.202)$ & $0.134(-0.110 ; 0.363)$ \\
\hline SCS & $0.124(-0.119 ; 0.354)$ & $-0.236(-0.451 ; 0.0334) *$ & $0.262(0.024 ; 0.473)$ * & $0.112(-0.132 ; 0.343)$ & $0.650(0.485 ; 0.770) * * *$ & $0.222(-0.019 ; 0.439) *$ & $0.003(-0.237 ; 0.243)$ & $-0.142(-0.370 ; 0.101)$ \\
\hline BRS & $-0.213(-0.431 ; 0.029)$ * & $-0.177(-0.401 ; 0.066)$ & $0.112(-0.132 ; 0.343)$ & $0.153(-0.091 ; 0.379)$ & $0.060(-0.183 ; 0.296)$ & $0.017(-0.224 ; 0.256)$ & $0.109(-0.135 ; 0.340)$ & $-0.065(-0.300 ; 0.178)$ \\
\hline LSQ & $-0.261(-0.472 ;-0.022) * *$ & $0.088(-0.155 ; 0.322)$ & $0.148(-0.095 ; 0.375)$ & $0.085(-0.158 ; 0.319)$ & $0.226(-0.015 ; 0.442) *$ & $0.067(-0.176 ; 0.302)$ & $-0.107(-0.338 ; 0.137)$ & $-0.191(-0.413 ; 0.051)$ \\
\hline FACIT-SP & $0.116(-0.136 ; 0.353)$ & $-0.150(-0.384 ; 0.101)$ & NA & $0.169(-0.083 ; 0.400)$ & $0.513(0.303 ; 0.675) * * *$ & $0.361(0.124 ; 0.559)$ ** & $0.160(-0.091 ; 0.392)$ & $0.046(-0.204 ; 0.291)$ \\
\hline AUDIT & $-0.074(-0.309 ; 0.169)$ & $-0.142(-0.370 ; 0.102)$ & $0.111(-0.133 ; 0.342)$ & $0.067(-0.176 ; 0.302)$ & $0.143(-0.100 ; 0.371)$ & $0.253(0.013 ; 0.465) * *$ & $-0.001(-0.242 ; 0.239)$ & $0.015(-0.226 ; 0.255)$ \\
\hline
\end{tabular}

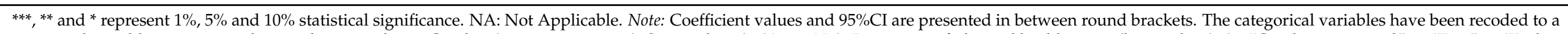

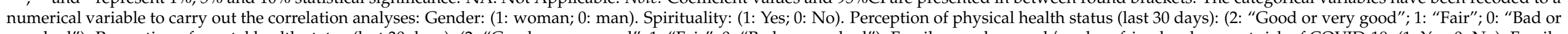

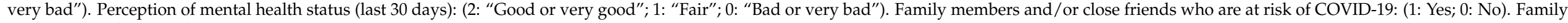
members and/or close friends who have died due to COVID-19: (1: Yes; 0: No). Changes implemented since the beginning of the pandemic: (2: "I moved"; 1 : "Isolation from my parents"; 0: "None").

Table 5. Associations between different psychological outcomes and Health Sciences students' practices.

\begin{tabular}{|c|c|c|c|}
\hline & Number of Weekly Hours in the Health Institution & Freedom Perceived while Performing Your Practices & Supervision Perceived while Performing Your Practices \\
\hline PSS-14 & $-0.104(-0.340 ; 0.143)$ & $-0.408(-0.593 ;-0.183) * * *$ & $-0.101(-0.337 ; 0.146)$ \\
\hline AAQ-II & $-0.039(-0.276 ; 0.203)$ & $-0.323(-0.522 ;-0.089) * *$ & $0.067(-0.176 ; 0.303)$ \\
\hline PHQ-4 & $-0.006(-0.246 ; 0234)$ & $-0.270(-0.479 ;-0.032) * *$ & $0.054(-0.189 ; 0.291)$ \\
\hline BRS & $-0.231(-0.446 ; 0.010) *$ & $-0.169(-0.394 ; 0.074)$ & $-0.204(-0.423 ; 0.038) *$ \\
\hline LSQ & $-0.027(-0.266 ; 0.215)$ & $0.051(-0.192 ; 0.287)$ & $0.046(-0.197 ; 0.282)$ \\
\hline FACIT-SP & $0.038(-0.211 ; 0.283)$ & $0.110(-0.141 ; 0.349)$ & $-0.178(-0.408 ; 0.073)$ \\
\hline AUDIT & $-0.054(-0.291 ; 0.188)$ & $-0.167(-0.392 ; 0.076)$ & $0.064(-0.179 ; 0.300)$ \\
\hline
\end{tabular}

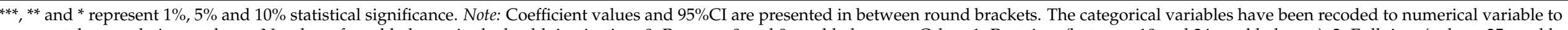

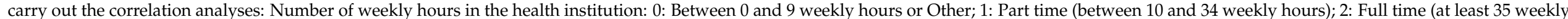

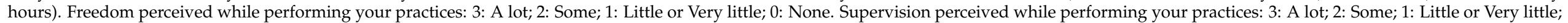
0 : None. 


\section{Discussion}

The objective of this study was to analyze the impact of the preventative measures and restrictions associated with the COVID-19 pandemic on multiple mental health and psychological well-being indicators in the Health Sciences course at the University of Seville. The main results indicate that $94.12 \%$ acknowledged having received no psychoemotional aid or support in most of the cases from their institution during the COVID-19 pandemic period. Allied to this, a positive correlation is to be noted between stress perception and anxiety and depression, and how all three relate among each other given the scales used. In addition, a positive correlation is evidenced between spirituality and compassion, as well as a negative correlation of stress, anxiety, and depression with spirituality and compassion. Alcohol consumption has increased during the COVID-19 pandemic [26], finding a moderate risk of developing an alcohol dependence in $35.82 \%$ of the students. Likewise, an association was evidenced between a bad or very bad perception of health status with more perceived stress, higher distress level, and less psychological resilience and, therefore, greater risk of presenting anxiety and/or depression symptoms. An association was also found between the students with family members and/or close friends at risk of contracting COVID-19 or who died due to the disease and those who were isolated from their parents when compared to the participants who did not implement any isolation measure, with more psychological distress and, therefore, greater predominance of anxiety and/or depression.

Regarding lack of psychoemotional aid or support by their institution during the COVID-19 pandemic period, most of the participants pointed to a lack of support. In relation to that, in early March, a study was conducted considering that young individuals, university students among them, presented the possibility of developing emotional disorders, which is why prevention and intervention programs to reduce stress levels should be devised and promoted by the educational institutions themselves [27]. Allied to the above, another study indicated that early identification of Burnout syndrome symptoms (sleep deprivation, academic overload, imbalance between personal and academic life, life crises during studies, death of a family member, or low perception of self-efficacy, among others) could reduce the number of psychosocial problems [28] that can emerge in academic life, hence the importance of emotional support. At the institutional level, a lack of time for a good diet, rest, and self-care [29] and the use of digital platforms for learning have also been pointed out as factors that generate personal frustration [30].

Regarding stress, previous studies of population quarantine situations showed that there was a psychological impact of relevant intensity, even with long-term effects. During the 2003 SARS epidemic, it was shown that sleep was one of the first aspects affected by stress [31]. However, in addition to the assessed symptoms, sleep changes can constitute a disease by themselves, and it is well-known that they are not only associated with psychiatric disorders but also with alterations in various systems. Recent studies analyzed the impact of the COVID-19 pandemic on the mental health of the population [32], but the information about sleep changes is quite limited.

There are studies that support the results obtained in this intervention that higher compassion and spirituality levels are negatively correlated with the perception of stress, anxiety, and depression. Similarly to the current study, a study conducted among adolescents showed a strong and negative relationship between self-compassion and depression [33]. Other studies also identify men as with a higher level of self-compassion [34] when compared to women [35]. Other previous studies have indicated that compassion for others, by others, and self-compassion are positively correlated with commitment to life, with the possibility of asserting that the greater this commitment, the greater the satisfaction and the lower the anxiety and stress levels [36]. The inclusion of spirituality in assistance provided is essential for comprehensive care [37].

In relation to coping strategies, in a study conducted in Colombia [38], several strategies have been proposed, with maintenance of good eating and sleeping habits among the most noticeable, as supported by other authors. Recent evidence supports that lower 
adherence to many healthy lifestyles is associated with worse results in several psychiatric disorders [39]. As strategies for the management of emotions, the performance of breathing and mindfulness exercises before initiating and at the end of care activities has been proposed. The UNESCO recommends yoga and meditation as tools to control breathing and help young individuals to improve their anxiety levels. Additionally, in the case of yoga, the opportunity of doing physical exercise contributes even more benefits to the mind [40].

Furthermore, in the specific case of mindfulness practice, it has been proven to be an efficient tool to promote resilience among physicians [41].

Regarding the association between anxiety and/or depression symptoms, isolation, psychological distress, and predominance of anxiety and/or depression, a previous study conducted with Spanish students showed that $62 \%$ of the interviewees suffered high anxiety levels [42], a percentage that is similar to the values detected in studies conducted in the general Chinese population during COVID-19 [43]. Regarding the above, previous studies have associated social isolation or confinement with an increase in the feeling of loneliness and with the perception that COVID-19 exerted a greater impact on everyday life, although there is an association between a certain reduction in the feeling of loneliness and greater social support [44]. In the case of Spanish nursing students, a previous study aimed to describe the perceptions and experiences of nursing students who cared for patients with COVID-19 symptoms in the early stages of the outbreak. Their findings showed that many participants experienced feelings of stress, fear, and sadness due to emotional exhaustion caused by the pressure of having to provide adequate care and the lack of experience in certain procedures that had to be performed, which also affected the fear of being infected by a lack of protection, and also infecting family members and feeling lonely when they worked without the supervision of qualified personnel [3].

The findings of the study conducted in the Private Technical University of Loja (Ecuador) are similar: psychological inflexibility and loneliness mediated the impact of stress on anxiety and depression symptoms in participants, regardless of gender and the history of a positive COVID-19 diagnosis [45].

In addition to this, this study showed a positive correlation between the number of hours of practice and less psychological resilience with a certain predominance of presenting anxiety and depression symptoms, which coincides with another study showing that nurses who act on the front line who presented greater resilience with emotional support had fewer anxiety symptoms [46]. Furthermore, other studies identified that the risk of suffering burnout was lower and characterized by a greater use of emotional strategies to reduce stress [25], and another study with physiotherapy study showed a relationship between stress and type D personality and stomatognathic system disorders [47].

Finally, this study had several limitations and strengths that must be acknowledged. In the first place, as the data are cross-sectional, no causality can be established, only associations between variables. Without longitudinal data, it is not possible to show the time precedence of the predictors selected. In the second place, regarding the sample, it is worth noting the sample loss and lack of participation in this type of study, as already pointed out in previous surveys [48]. In addition, the recruitment system and data collection through an online survey limited generalization and hindered real control of the participants. In the third place, as this study was conducted in only one university, it is difficult to generalize its results to other universities or academic curricula.

However, the use of validated questionnaires in Spanish allowed a reduction of some of the possible biases. Allied with this, this study was conducted simultaneously in the Private Technical University of Loja (Ecuador), which allows for a comparative study of both samples. In addition, as this study will be implemented in other universities, it will include data on instrumental social support for students, especially those with symptoms of anxiety and depression. 


\section{Conclusions}

Stress and anxiety levels have been high during the last year (from March 2020), for different reasons, with the following standing out: lack of knowledge about the pandemic, fear that a family member could contract COVID-19 and die, prolonged confinement periods throughout the year (from March 2020 to June 2020), and limited emotional support received from the institution. There has also been an increase in the feeling of loneliness, which was reduced with greater social support and in the cases of students who were not isolated from their parents.

As the most noticeable strategy, we identified mindfulness, which can be applied to reduce stress and anxiety levels and improve psychological resilience.

Spirituality and compassion help reduce anxiety and perceived stress levels while also increasing satisfaction with life and enabling greater commitment to it.

As the health situation imposed by COVID-19 is considered long-lasting, the proposal is to plan short- and long-term strategies for promotion and intervention regarding the mental health of students and future health care workers. Therefore, subsequent studies need to devise more specific strategies for emotional support in students.

The results of this study do not provide definitive evidence, because it was a pilot study with a small sample, and although a big effort was made to collect participants (as it explained above), a designed cross-sectional descriptive is needed. However, this study can be considered as a first step in an approach to the impact of the confinement measures associated with COVID-19 on multiple mental health and psychological wellbeing indicators in Health Sciences students.

Author Contributions: Conceptualization: R.d.-D.-C. and C.M.-d.-C.; Methodology: R.d.-D.-C. and P.B.S.; Software and formal analysis: A.-M.V.-M.; Validation: R.d.-D.-C. and A.-M.V.-M.; WritingOriginal draft preparation: R.d.-D.-C., C.M.-d.-C. and A.-M.V.-M.; Writing-Review and editing: R.d.-D.-C., C.M.-d.-C., A.-M.V.-M. and P.B.S.; Funding acquisition: P.B.S. All authors have read and agreed to the published version of the manuscript.

Funding: This research has been funded by the Private Technical University of Loja, Ecuador: PROY_INV_CCSAL_2020_2731.

Institutional Review Board Statement: To elaborate our questionnaire, a previous request was made to the Andalusian Research Ethics Committees with favorable resolution to conduct it on 15 March 2021, since the study is presented following the requirements set forth in Law No. 14/2007, dated 3 July, regarding Biomedical Research, and its conduction is pertinent; meets the necessary protocol suitability requirements in relation to the study objectives and the foreseeable risks and discomforts for the subjects are justified; there is adequacy in both the procedure to obtain the informed consent and in the foreseen compensation to the subjects for any damage that might arise from their participation in the study; the scope of the economic compensations foreseen does not interfere with respect of the ethical precepts; and the Researchers' ability and the available means are appropriate to conduct the study. The study was approved by the Andalusian Research Ethics Committee, Spain (Code: 2699-N-20).

Informed Consent Statement: Informed consent was obtained from all subjects involved in the study.

Data Availability Statement: The authors declare to be responsible for conducting the protocols established by their respective centers to evaluate the volunteers included in the study for scientific research and disclosure purposes and ensure that the requirement of having informed all the study subjects has been complied with, that the participants' informed consent to participate in the study has been obtained in writing, and that they are in possession of such documents. Therefore, before their incorporation to this study, all the participants were verbally informed about the procedure that was conducted and they digitally agreed with the informed consent to participate in the research and answer the survey. The main researcher explained the study purpose to them, they understand that their participation is voluntary and that they can exit the questionnaire at their will without having to give any explanations. The authors declare that, in this research, the participants' data privacy was ensured and state that the published paper does not infringe the normative regarding personal data protection, safeguarding the subjects' identity, since the IP addresses were randomized. The 
participants consented to the computerized treatment of the data obtained for scientific purposes, according to the legal rules, as per Organic Law No. 3/2018 regarding Protection of Personal Data and Guarantee of the Digital Rights.

Conflicts of Interest: We, the authors, declare that there has been no conflict of interests.

\section{References}

1. Bu, J.; Deng, Z.; Liu, H.; Li, J.; Wang, D.; Yang, Y.; Zhong, S. Current Methods and Prospects of Coronavirus Detection. Talanta 2021, 225, 121977. [CrossRef] [PubMed]

2. Alocución de Apertura del Director General de la OMS en la Rueda de Prensa Sobre la COVID-19 Celebrada el 11 de Marzo de. 2020. Available online: https:/ /www.who.int/es/director-general/speeches/detail/who-director-general-s-opening-remarksat-the-media-briefing-on-covid-19---11-march-2020 (accessed on 28 July 2021).

3. BOE.es-BOE-A-2020-3692 Real Decreto 463/2020, de 14 de Marzo, por el que se Declara el Estado de Alarma para la Gestión de la Situación de crisis Sanitaria Ocasionada por el COVID-19. Available online: https: / /www.boe.es/buscar/doc.php?id=BOE-A-20 20-3692 (accessed on 28 July 2021).

4. Rodríguez-Almagro, J.; Hernández-Martínez, A.; Romero-Blanco, C.; Martínez-Arce, A.; del C. Prado-Laguna, M.; García-Sanchez, F.J. Experiences and Perceptions of Nursing Students during the COVID-19 Crisis in Spain. Int. J. Environ. Res. Public Health 2021, 18, 10459. [CrossRef] [PubMed]

5. Cao, W.; Fang, Z.; Hou, G.; Han, M.; Xu, X.; Dong, J.; Zheng, J. The Psychological Impact of the COVID-19 Epidemic on College Students in China. Psychiatry Res. 2020, 287, 112934. [CrossRef]

6. Serrano-Ripoll, M.J.; Meneses-Echavez, J.F.; Ricci-Cabello, I.; Fraile-Navarro, D.; Fiol-deRoque, M.A.; Pastor-Moreno, G.; Castro, A.; Ruiz-Pérez, I.; Zamanillo Campos, R.; Gonçalves-Bradley, D.C. Impact of Viral Epidemic Outbreaks on Mental Health of Healthcare Workers: A Rapid Systematic Review and Meta-Analysis. J. Affect. Disord. 2020, 277, 347-357. [CrossRef]

7. Recomendaciones COVID-19/New Health Foundation. Available online: https://www.newhealthfoundation.org/ recomendaciones-covid-19/ (accessed on 10 July 2021).

8. Prince, M.; Patel, V.; Saxena, S.; Maj, M.; Maselko, J.; Phillips, M.R.; Rahman, A. No Health without Mental Health. Lancet 2007, 370, 859-877. [CrossRef]

9. Fu, W.; Yan, S.; Zong, Q.; Anderson-Luxford, D.; Song, X.; Lv, Z.; Lv, C. Mental Health of College Students during the COVID-19 Epidemic in China. J. Affect. Disord. 2021, 280, 7-10. [CrossRef]

10. Mo, Y.; Deng, L.; Zhang, L.; Lang, Q.; Liao, C.; Wang, N.; Qin, M.; Huang, H. Work Stress among Chinese Nurses to Support Wuhan in Fighting against COVID-19 Epidemic. J. Nurs. Manag. 2020, 28, 1002-1009. [CrossRef]

11. Liang, Y.; Chen, M.; Zheng, X.; Liu, J. Screening for Chinese Medical Staff Mental Health by SDS and SAS during the Outbreak of COVID-19. J. Psychosom. Res. 2020, 133, 110102. [CrossRef]

12. Kang, L.; Li, Y.; Hu, S.; Chen, M.; Yang, C.; Yang, B.X.; Wang, Y.; Hu, J.; Lai, J.; Ma, X.; et al. The Mental Health of Medical Workers in Wuhan, China Dealing with the 2019 Novel Coronavirus. Lancet Psychiatry 2020, 7, e14. [CrossRef]

13. BOE.es-BOE-A-2020-13494 Royal Decree 956/2020, of 3 November, Extending the State of Alarm Declared by Royal Decree 926/2020, of 25 October, Declaring the State of Alarm to Contain the Spread of Infections Caused by SARS-CoV-2. Available online: https:/ /www.boe.es/eli/es/rd/2020/11/03/956/con (accessed on 15 November 2021).

14. Samper, M.B. Organic Law 3/2018, of December 5, Protection of Personal Data and Guarantee of Digital Rights. Available online: https: / / ecija.com/en/sala-de-prensa / organic-law-3-2018-of-december-5-protection-of-personal-data-and-guaranteeof-digital-rights / (accessed on 11 December 2018).

15. Viechtbauer, W.; Smits, L.; Kotz, D.; Budé, L.; Spigt, M.; Serroyen, J.; Crutzen, R. A Simple Formula for the Calculation of Sample Size in Pilot Studies. J. Clin. Epidemiol. 2015, 68, 1375-1379. [CrossRef]

16. Trujillo, H.M.; González-Cabrera, J.M. Psychometric Properties of the Spanish Version of the Perceived Stress Scale (PSS). Psicol. Conductual 2007, 15, 457-477.

17. Pontinen, H.M.; Swails, J.A. UCLA Loneliness Scale. Available online: https://fetzer.org/sites/default/files/images/ stories/pdf/selfmeasures/Self_Measures_for_Loneliness_and_Interpersonal_Problems_UCLA_LONELINESS.pdf (accessed on 16 December 2018).

18. Barraca-Mairal, J. Spanish Adaptation of the Acceptance and Action Questionnaire (AAQ). Int. J. Psychol. Psychol. Ther. 2004, 4, 505-515.

19. Rodríguez-Rey, R.; Alonso-Tapia, J.; Hernansaiz-Garrido, H. Reliability and Validity of the Brief Resilience Scale (BRS) Spanish Version. Psychol. Assess. 2016, 28, 101-110. [CrossRef]

20. World Health Organization. Global Status Report on Alcohol and Health 2018. Available online: https://www.who.int/ publications/i/item/9789241565639 (accessed on 27 September 2018).

21. Korff, V. Staggered Pain Care Measurement of Pain Intensity and Interference: Level 1. Int. Assoc. Study Pain 2012, $20,8$.

22. Khubchandani, J.; Brey, R.; Kotecki, J.; Kleinfelder, J.A.; Anderson, J. The Psychometric Properties of PHQ-4 Depression and Anxiety Screening Scale among College Students. Arch. Psychiatr. Nurs. 2016, 30, 457-462. [CrossRef]

23. Elices, M.; Carmona, C.; Pascual, J.C.; Feliu-Soler, A.; Martin-Blanco, A.; Soler, J. Compassion and Self-Compassion: Construct and Measurement. Mindfulness Compassion 2017, 2, 34-40. [CrossRef] 
24. Garcia-Campayo, J.; Navarro-Gil, M.; Andrés, E.; Montero-Marin, J.; López-Artal, L.; Marcos, M.; Demarzo, P. Validation of the Spanish Versions of the Long (26 Items) and Short (12 Items) Forms of the Self-Compassion Scale (SCS). Available online: https:/ /hqlo.biomedcentral.com/articles/10.1186/1477-7525-12-4 (accessed on 10 January 2014).

25. Rabitti, E.; Cavuto, S.; Iani, L.; Ottonelli, S.; De Vincenzo, F.; Costantini, M. The Assessment of Spiritual Well-Being in Cancer Patients with Advanced Disease: Which Are Its Meaningful Dimensions? BMC Palliative Care 2020, 19, 1-8. [CrossRef]

26. Di Monte, C.; Monaco, S.; Mariani, R.; Di Trani, M. From Resilience to Burnout: Psychological Features of Italian General Practitioners during COVID-19 Emergency. Front. Psychol. 2020, 11, 2476. [CrossRef]

27. Jacob, L.; Smith, L.; Armstrong, N.C.; Yakkundi, A.; Barnett, Y.; Butler, L.; McDermott, D.T.; Koyanagi, A.; Shin, J.I.; Meyer, J.; et al. Alcohol Use and Mental Health during COVID-19 Lockdown: A Cross-Sectional Study in a Sample of UK Adults. Drug Alcohol Depend. 2021, 219. [CrossRef]

28. Bitran, M.; Zúñiga, D.; Pedrals, N.; Echeverría, G.; Vergara, C.; Rigotti, A.; Puschel, K. Burnout in Students of Health-Care Professions. Risk and Protection Factors. Rev. Med. Chil. 2019, 147, 510-517. [CrossRef]

29. Arima, M.; Takamiya, Y.; Furuta, A.; Siriratsivawong, K.; Tsuchiya, S.; Izumi, M. Factors Associated with the Mental Health Status of Medical Students during the COVID-19 Pandemic: A Cross-Sectional Study in Japan. BMJ Open 2020, 10, 43728. [CrossRef]

30. Kapasia, N.; Paul, P.; Roy, A.; Saha, J.; Zaveri, A.; Mallick, R.; Barman, B.; Das, P.; Chouhan, P. Impact of Lockdown on Learning Status of Undergraduate and Postgraduate Students during COVID-19 Pandemic in West Bengal, India. Child. Youth Serv. Rev. 2020, 116, 105194. [CrossRef]

31. Moldofsky, H.; Patcai, J. Chronic Widespread Musculoskeletal Pain, Fatigue, Depression and Disordered Sleep in Chronic Post-SARS Syndrome; a Case-Controlled Study. BMC Neurol. 2011, 11, 37. [CrossRef]

32. Altena, E.; Baglioni, C.; Espie, C.A.; Ellis, J.; Gavriloff, D.; Holzinger, B.; Schlarb, A.; Frase, L.; Jernelöv, S.; Riemann, D. Dealing with Sleep Problems during Home Confinement Due to the COVID-19 Outbreak: Practical Recommendations from a Task Force of the European CBT-I Academy. J. Sleep Res. 2020, 29, e13052. [CrossRef]

33. Ferrari, M.; Yap, K.; Scott, N.; Einstein, D.A.; Ciarrochi, J. Self-Compassion Moderates the Perfectionism and Depression Link in Both Adolescence and Adulthood. PLoS ONE 2018, 13, e0192022. [CrossRef]

34. Lee, E.E.; Govind, T.; Ramsey, M.; Wu, T.C.; Daly, R.; Liu, J.; Tu, X.M.; Paulus, M.P.; Thomas, M.L.; Jeste, D.V. ARTICLE Compassion toward Others and Self-Compassion Predict Mental and Physical Well-Being: A 5-Year Longitudinal Study of 1090 Community-Dwelling Adults across the Lifespan. Transl. Psychiatry 2021, 11, 1-9. [CrossRef]

35. Aranda Auserón, G.; Elcuaz Viscarret, M.R.; Fuertes Goñi, C.; Güeto Rubio, V.; Pascual Pascual, P.; Sainz de Murieta García de Galdeano, E. Evaluation of the Effectiveness of a Mindfulness and Self-Compassion Program to Reduce Stress and Prevent Burnout in Primary Care Health Professionals. Aten. Primaria 2018, 50, 141-150. [CrossRef]

36. Davalos-Batallas, V.; Vargas-Martínez, A.M.; Bonilla-Sierra, P.; Leon-Larios, F.; Lomas-Campos, M.D.L.M.; Vaca-Gallegos, S.L.; de Diego-Cordero, R. Compassionate Engagement and Action in the Education for Health Care Professions: A Cross-Sectional Study at an Ecuadorian University. Int. J. Environ. Res. Public Health 2020, 17, 5425. [CrossRef]

37. Ienne, A.; Aurea Quintella Fernandes, R.; Claudia Puggina, A.; Cláudia Puggina, A.; Anna, E. Does the Spirituality of Nurses Interfere in the Record of Spiritual Suffering Diagnosis? RESEARCH I PESQUISA. Esc. Anna Nery 2018, 22. [CrossRef]

38. Cantor-Cruz, F.; McDouall-Lombana, J.; Parra, A.; Martin-Benito, L.; Paternina Quesada, N.; González-Giraldo, C.; Cárdenas Rodríguez, M.L.; Castillo Gutiérrez, A.M.; Garzón-Lawton, M.; Ronderos-Bernal, C.; et al. Mental Health Care of Health Workers During Covid-19: Recommendations Based on Evidence and Expert Consensus. Rev. Colomb. Psiquiatr. 2021. [CrossRef] [PubMed]

39. How Do We Protect the Mental Health of Students in a Pandemic. Available online: https://en.unesco.org/news/how-do-weprotect-mental-health-students-pandemic (accessed on 10 August 2021).

40. Ozamiz-Etxebarria, N.; Dosil-Santamaria, M.; Picaza-Gorrochategui, M.; Idoiaga-Mondragon, N. Niveles de Estrés, Ansiedad y Depresión En La Primera Fase Del Brote Del COVID-19 En Una Muestra Recogida En El Norte de España. Cad. Saude Publica 2020, 36. [CrossRef]

41. Krogh, E.; Medeiros, S.; Bitran, M.; Langer, Á.I. Mindfulness y La Relación Clínica: Pasos Hacia Una Resiliencia En Medicina. Rev. Médica de Chile 2019, 147, 618-627. [CrossRef]

42. Díaz-Jiménez, R.M.; Caravaca-Sánchez, F.; Martín-Cano, M.C.; De La Fuente-Robles, Y.M. Anxiety Levels among Social Work Students during the COVID-19 Lockdown in Spain. Soc. Work Health Care 2020, 59, 681-693. [CrossRef]

43. Wang, C.; Pan, R.; Wan, X.; Tan, Y.; Xu, L.; Ho, C.S.; Ho, R.C. Immediate Psychological Responses and Associated Factors during the Initial Stage of the 2019 Coronavirus Disease (COVID-19) Epidemic among the General Population in China. Int. J. Environ. Res. Public Health 2020, 17, 1729. [CrossRef]

44. Tull, M.T.; Edmonds, K.A.; Scamaldo, K.M.; Richmond, J.R.; Rose, J.P.; Gratz, K.L. Psychological Outcomes Associated with Stay-at-Home Orders and the Perceived Impact of COVID-19 on Daily Life. Psychiatry Res. 2020, 289, 113098. [CrossRef]

45. Sierra, P.B.; Manrique, G.A.; Hidalgo-Andrade, P.; Ruisoto, P. Psychological Inflexibility and Loneliness Mediate the Impact of Stress on Anxiety and Depression Symptoms in Healthcare Students and Early-Career Professionals during COVID-19. Front. Psychol. 2021, 4094. [CrossRef]

46. Labrague, L.J.; De los Santos, J.A.A. COVID-19 Anxiety among Front-Line Nurses: Predictive Role of Organisational Support, Personal Resilience and Social Support. J. Nurs. Manag. 2020, 28, 1653-1661. [CrossRef] 
47. Rushton, C.H.; Swoboda, S.M.; Reller, N.; Skarupski, K.A.; Prizzi, M.; Young, P.D.; Hanson, G.C. Mindful Ethical Practice and Resilience Academy: Equipping Nurses to Address Ethical Challenges. Am. J. Crit. Care 2021, 30, e1-e11. [CrossRef]

48. Gęskka, M.; Kołodziej, Ł.; Dalewski, B.; Pałka, Ł.; Sobolewska, E. The Influence of the COVID-19 Pandemic on the Stress Levels and Occurrence of Stomatoghnatic System Disorders (SSDs) among Physiotherapy Students in Poland. J. Clin. Med. 2021, 10, 3872. [CrossRef] 